PARADIGMA JURNAL KAJIAN BUDAYA Vol. 6 No. 1 (2016): 123-143

\title{
PESONA JAWA DALAM PUISI RUSIA
}

\author{
Thera Widyastuti' dan Banggas Limbong ${ }^{1}$ \\ ${ }_{1}^{1}$ Program Studi Rusia, Fakultas IImu Pengetahuan Budaya, Universitas Indonesia, \\ thera.widyastuti@gmail.com, banggaslimbong@yahoo.com
}

DOI: 10.17510/paradigma.v6i1.85.

\begin{abstract}
This research will analyze Russian poems by using the approach of sociology of literature. Poetry is a popular form in Russian literature. The presence of the poets with their works make people in the world know Russian literature. The poets's journey to all over the world provide experiences that inspire their works. Nusantara as a region famous for its natural resources has attracted Europeans, and has inspired the Russian poets Esperovich Esper Ukhtomsky, Konstantin Dmitriyevich Balmont, Valery Yakovlevich Bryusov and Vladimir Yurievich Elsner. They wrote poems the beauty of the natural and cultural heritage, especially in Java. Borobudur, traditional music, traditional dance, and Botanical Gardens became theme in their poetry.
\end{abstract}

\section{KEYWORDS}

Poem; Russian; Nusantara; Java; poet.

\section{Pendahuluan}

Kesusastraan Rusia berawal dari mitos yang berkembang pada periode kesusastraan Rusia kuno. Kepercayaan pada dewa-dewi membuat bangsa Rusia memercayai bahwa dunia ini dikuasai alam. Seiring dengan waktu, kesusastraan Rusia berkembang pesat sejak temuan huruf Cyrilic pada abad IX. Peran agama Kristen ortodoks yang masuk ke Rusia, menggantikan paganisme yang telah dimodifikasi sedemikiran rupa, menjadi ciri khas bangsa Rusia. Kehadiran misionaris di Rusia, selain untuk menyebarkan agama Kristen ortodoks, juga mengajarkan membaca dan menulis kepada masyarakat Rusia yang mayoritas buta huruf. Pada masa itu, hanya gerejawan dan bangsawan yang melek huruf. Bentuk karya sastra tulis pertama di 
Rusia adalah liturgi yang ditulis oleh para pendeta dan juga terjemahan dari berbagai kitab yang berasal dari Byzantium.

Perkembangan kesusastraan Rusia mencapai puncaknya pada abad XIX, saat muncul para pengarang yang menciptakan karya terkenal berbentuk puisi, cerita pendek, dan novel. Bangsa Rusia menyukai karya sastra mereka, bahkan banyak di antaranya yang juga digemari di mancanegara.

Salah satu bentuk karya sastra yang digemari di Rusia adalah puisi. Penyair memilih kata-kata yang tepat dan indah, serta disusun secara baik. Puisi merupakan hasil kreativitas manusia yang diwujudkan lewat susunan kata yang mempunyai makna. Susunan kata itu memiliki pola rima (persajakan) tertentu. ${ }^{1}$ Puisi itu mengekspresikan pemikiran yang membangkitkan perasaan, merangsang imajinasi, pancaindera dalam susunan yang berirama. Puisi merupakan rekaman dan interpretasi pengalaman manusia yang penting. ${ }^{2}$

Kehadiran penyair terkenal Rusia, Aleksander Sergeyevich Pushkin (1799-1837) memberikan pengaruh besar pada penyair Rusia lain. la memperkenalkan penggunaan bahasa vernakular dan gaya penceritaan yang menggabungkan drama, roman, dan satire.

Salah satu puisinya yang sangat terkenal berjudul Руслан и Людмила (Ruslan dan Lyudmila) diterbitkan pada 1820. Puisi itu panjang. mengisahkan penculikan Lyudmila, anak perempuan Pangeran Vladimir dari Kiev oleh seorang penyihir jahat dan upaya dari seorang ksatria bernama Ruslan yang gagah dan berani untuk menemukan dan menyelamatkan sang putri.

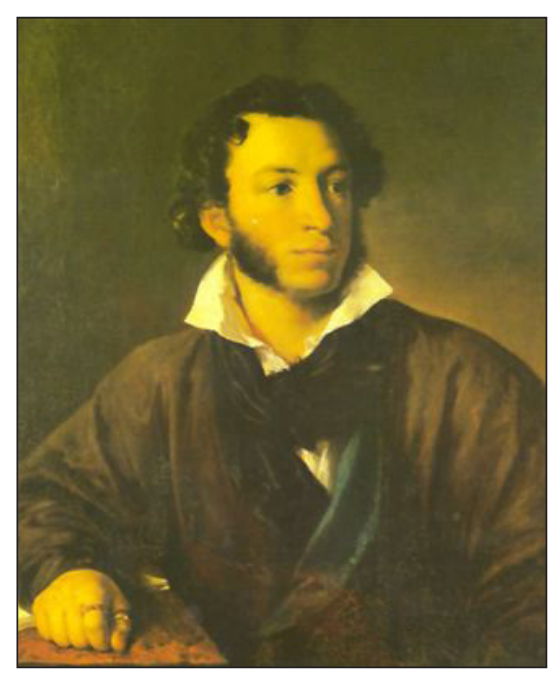

Foto 1. Alexander Pushkin Pushkin (Sumber: lihat Bibliografi).

1. Suminto A. Sayut, i. Puisi dan Pengajarannya: Sebuah Pengantar (Semarang: IKIP Pres, 1985),12-13.

2. Rahmat Djoko Pradopo, Pengkajian Puisi: Analisis Strata Norma dan Analisis Struktural dan Semiotik. (Yogyakarta: GadjahMada University Press, 2002), 7. 
Semangat penyair Rusia untuk berkarya terus berlanjut meskipun kematian Aleksander Sergeyevich Pushkin dalam duel dengan Georges d'Ánthes terjadi pada 1837. Kehadiran penyair muda menandakan bahwa puisi menjadi bagian dari kehidupan mereka dan tetap digemari hingga kini.

\section{Pengaruh Barat dan Timur}

Rusia adalah salah satu negara terbesar dan terluas di dunia. Letak geografis Rusia yang terbentang di antara dua benua, Eropa dan Asia, serta latar belakang sejarah Rusia memberi pengaruh besar pada kehidupan bangsa Rusia. Pembentukan karakter bangsa Rusia juga dipengaruhi bangsa Eropa dan Asia. Hubungan yang terjalin di berbagai bidang, terutama di bidang ekonomi dan politik di kedua benua, memberi pengaruh pada kehidupan sosial budaya masyarakat Rusia.

Seorang filsuf terkenal Rusia, Nikolai Aleksandrovich Berdyaev (1874-1948) mengemukakan pendapatnya mengenai pengaruh Barat dan Timur di dalam bukunya Русская Идея (Russian Idea) yang diterjemahkan ke dalam bahasa Inggris oleh Robert M. French sebagai berikut.

The Russian people is not purely European and it is not purely Asiatic. Russia is a complete section of the world - a colossal East-West. It unites two worlds, and within the Russian soul two principles are always engaged in strife - the Eastern and the Western. (Berdyaev 1992, 2).

Kutipan di atas menggambarkan bahwa bangsa Rusia memiliki hubungan dengan Barat dan Timur. Pengaruh Barat dan Timur sangat jelas terlihat pada berbagai aspek kehidupan masyarakat, serta pemikiran dari Barat dan Timur memengaruhi pola pikir bangsa itu.

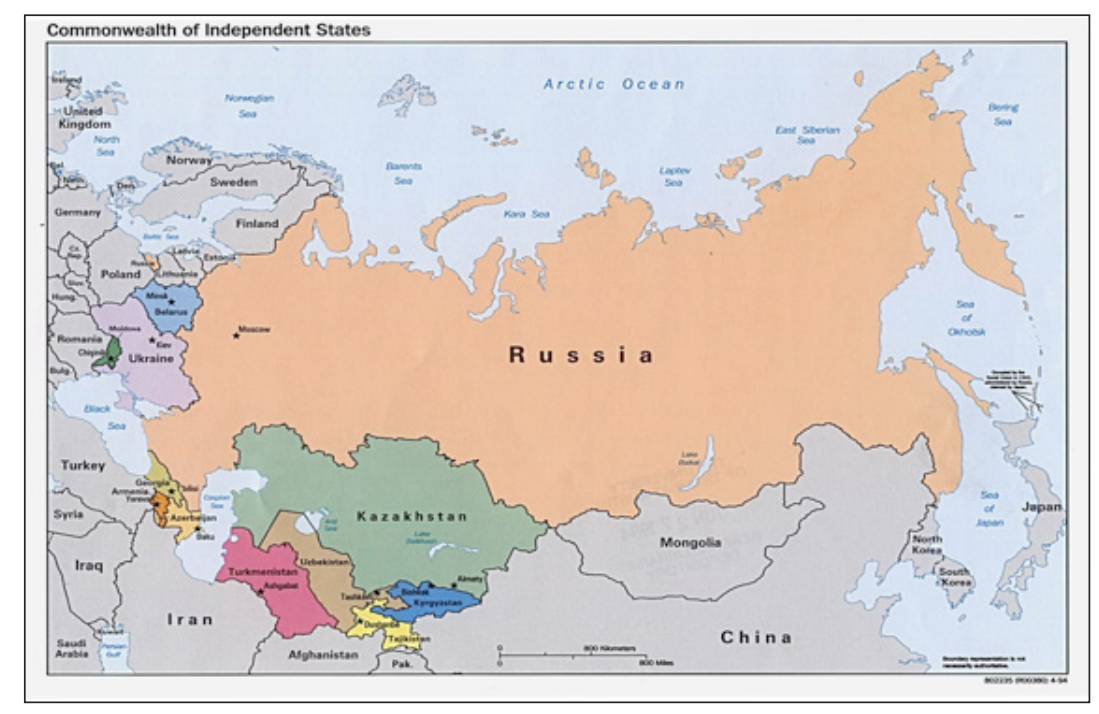

Peta 1. Rusia (Sumber: lihat Bibliografi). 
Westernisasi yang dilakukan oleh Tsar Pyotr Agung (1672-1725) pada abad XVII menjadikan bangsa Rusia sejajar dengan bangsa Eropa lain. Perjalanan selama setahun (1697-1698) ke Eropa (Barat) menjadi inspirasi baginya dalam melakukan perubahan di bidang politik, pemerintahan, dan perekonomian. Tsar Pyotr Agung memanfaatkan perjalanan itu untuk memperoleh pengetahuan dan teknologi dari Barat serta mempekerjakan ahli dan pakar asing di Rusia. Pengaruh Barat memberikan dampak positif pada kemajuan bangsa Rusia.

Namun, kekalahan Rusia dalam invasi bangsa Mongolia menimbulkan pandangan negatif tentang Timur. Dampak dari invasi itu, bangsa Mongolia dianggap sebagai bangsa yang biadab, perusak, dan rakus. ${ }^{3}$ Sebagian bangsa Rusia memandang mereka sebagai bangsa barbar. Kejatuhan Kota Kiev ke tangan bangsa Mongol meninggalkan persoalan yang cukup serius dalam bidang politik dan ekonomi. Dalam bidang politik, banyak pangeran yang tunduk pada kekuasaan bangsa Mongolia dan mengurangi tingkat kepercayaan rakyat pada penguasa pada masa itu.

Pengaruh Barat dan Timur menjadikan bangsa Rusia unik. Setiap pengaruh memiliki ciri khas yang selanjutnya melebur ke dalam karakter bangsa Rusia dan kehidupan sehari-hari mereka.

\section{Kebudayaan dan Masyarakat}

Dalam kehidupan masyarakat, kebudayaan memegang peran penting. Menurut Ralph Linton, seorang antropolog dari Amerika Serikat, kebudayaan adalah seluruh cara kehidupan masyarakat yang mana pun dan tidak hanya mengenai sebagian dari cara hidup itu, yaitu bagian yang dianggap masyarakat lebih tinggi atau lebih diinginkan. Setiap masyarakat memiliki kebudayaan, betapa sederhana pun dan setiap manusia adalah makhluk berbudaya dalam arti menjadil bagian dari suatu kebudayaan. ${ }^{4}$

Kebudayaan menunjuk ke berbagai aspek kehidupan yang meliputi cara berlaku dan bersikap, kepercayaan, dan hasil kegiatan manusia untuk suatu masyarakat atau kelompok tertentu. Unsur kebudayaan yang dianggap sebagai cultural universal yaitu (1) peralatan dan perlengkapan hidup manusia (pakaian, rumah, peralatan rumah tangga, senjata, alat transportasi), (2) mata pencaharian hidup dan sistem-sistem ekonomi (pertanian, peternakan, sistem produksi, sistem distribusi), (3) sistem kemasyarakatan (sistem kekerabatan, organisasi politik, sistem hukum, sistem perkawinan), (4) bahasa (lisan maupun tertulis), (5) kesenian (seni rupa, seni suara, seni lukis, dan sebagainya), (6) sistem pengetahuan, dan (7) religi (sistem

3. Michael Kort. A Brief History of Russia. (New York: Facts On File, Inc, 2008), 14.

4. T.O. Ihromi (ed.), Pokok-pokok Antropologi Budaya. (Jakarta: Yayasan Obor Indonesia,1996), 18. 
kepercayaan). ${ }^{5}$ Kebudayaan bangsa Rusia meliputi ketujuh unsur universal itu yang melebur, dan ada pengaruh Barat dan Timur yang membuat kebudayaan bangsa Rusia unik.

\section{Nusantara dan Pulau Jawa}

Indonesia, atau yang dikenal sebagai Nusantara, terletak di Asia dan keberadaannya telah menarik perhatian dunia. Nama Nusantara berasal dari dua kata bahasa Sanskerta, yaitu nusa yang berarti 'pulau' dan antara yang berarti 'luar'. Nusantara digunakan untuk menyebut pulau-pulau di luar Majapahit (Jawa). Perkataan Nusantara diperoleh dari Sumpah Palapa Patih Gajah Mada yang diucapkan dalam upacara pengangkatannya sebagai Patih Amangkubhumi Kerajaan Majapahit yang tertulis di dalam Kitab Pararaton (Raja-raja).

Pulau Jawa panjangnya lebih dari $1.200 \mathrm{~km}$ dan lebarnya $500 \mathrm{~km}$ bila diukur dari ujung-ujungnya yang terjauh. Letaknya di tepi sebelah selatan Kepulauan Indonesia, kurang lebih tujuh derajat di sebelah selatan garis khatulistiwa. Pulau Jawa adalah bagian dari gugusan kepulauan Sunda besar dan paparan Sunda. Pulau Jawa memiliki banyak gunung berapi. ${ }^{6}$

Pulau Jawa hanya merupakan tujuh persen dari seluruh daratan kepulauan Indonesia. Pulau Jawa memiliki daratan yang subur karena letaknya di antara benua Asia dan Australia, serta banyak gunung berapi, baik yang masih aktif dan tidak aktif dengan ketinggian antara 1.500 dan 3.500 di atas permukaan laut. ${ }^{7}$

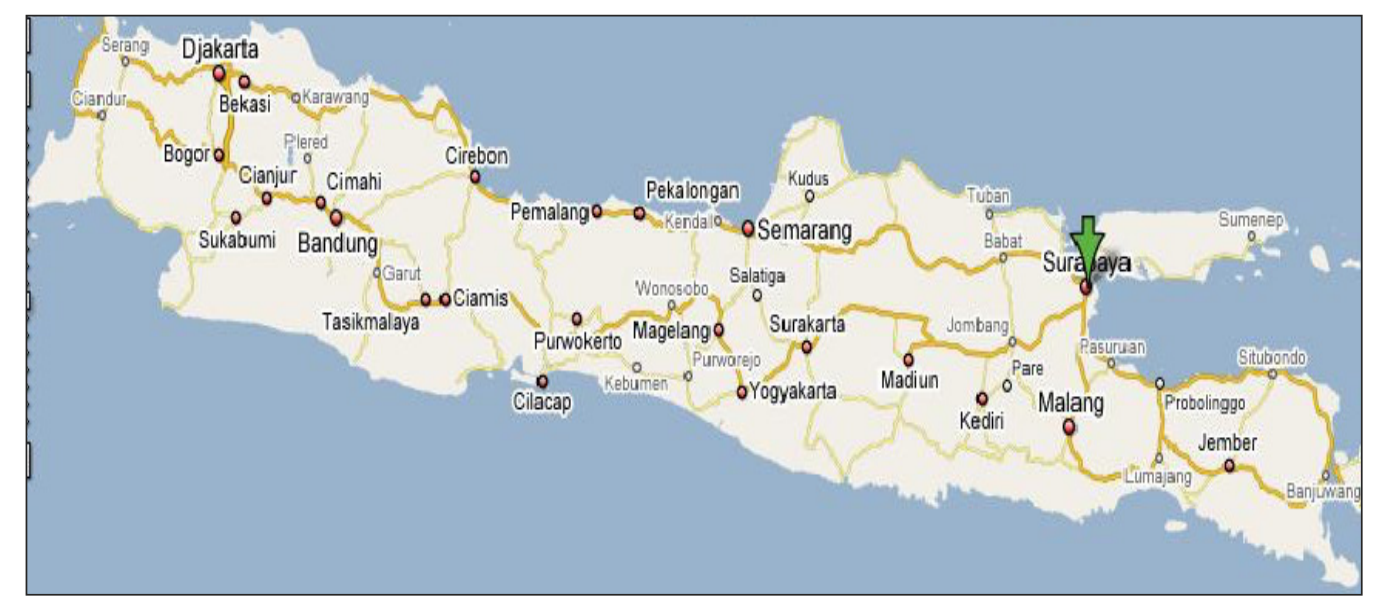

Peta 2. Pulau Jawa (sumber: lihat Bibliografi).

5. Soerjono Soekanto, Sosiologi: Suatu Pengantar. (Jakarta: P.T. Raja Grafindo Persada,1990), 176.

6. Khatulistiwa adalah garis imajiner yang membentang dari timur ke barat pada permukaan bumi dan persis setengah jalan antara Kutub Utara dan Selatan (titik utara dan selatan di Bumi). Khatulistiwa juga membagi bumi menjadi belahan bumi utara dan belahan bumi selatan dan merupakan jalur lintang penting untuk keperluan navigasi seperti $0^{\circ}$ dan semua pengukuran lain menuju utara atau selatan. Indonesia terletak di $6^{\circ}$ Lintang Utara - $11^{\circ} 08^{\prime}$ Lintang Selatan, dan dari $95^{\circ}$ Bujur Timur $-141^{\circ} 45^{\prime}$ Bujur Timur.

7. Koentjaraningrat, Kebudayaan Jawa. (Jakarta: Penerbit Balai Pustaka,1984), 3. 
Persentuhan antara Rusia dan Nusantara terjadi pada abad XIX. Pada masa itu, beberapa penyair Rusia pergi mengunjungi beberapa pulau di Nusantara. Mereka mengunjungi Sumatra, Sulawesi, dan Jawa. Keindahan dan kekayaan alam serta budaya Nusantara yang memesona menimbulkan kekaguman pada penyair Rusia dan mereka menuangkannya ke dalam karya mereka.

Penyair Esper Esperovich Ukhtomsky (1861-1921), Konstantin Dmitriyevich Balmont (1867-1942), Valery Yakovlevich Bryusov (1873-1924), dan Vladimir Yurievich Elsner (1886-1964) menulis puisi tentang keindahan alam dan budaya Nusantara, khususnya Jawa. Borobudur, gamelan, tarian, dan Kebun Raya menjadi tema puisi mereka.

\section{Permasalahan}

Puisi yang mengangkat tema Jawa menarik untuk ditelitimengingat para penyair Rusia memiliki latar sosial budaya yang berbeda dengan masyarakat Jawa. Oleh karena itu, permasalahan yang diajukan pada riset ini sebagai berikut. Sesuai dengan latar sosialnya, bagaimana penyair Rusia memaknai Jawa di dalam puisi Яванская Плянская (Penari Jawa), Боро-будур (Borobudur), Яванская Поэма (Puisi Jawa), Яванская Сад (Kebun Jawa), dan Яванский Гамелан (Gamelan Jawa)?

\section{Metodologi Penelitian}

Penelitian ini akan menggunakan ancangan kualitatif. Ancangan itu dipandang tepat untuk menggambarkan dan menguraikan puisi yang akan dianalisis. Dalam penelitian kualitatif itu, akan digunakan teknik pengumpulan data yang saling melengkapi dan dilakukan dalam upaya memperoleh hasil yang komprehensif berupa studi literatur dan dokumen.

Studi literatur dilakukan untuk mengumpulkan data dan selanjutnya dipilah-pilah sesuai dengan permasalahan yang diajukan. Hal ini dilakukan pada literatur mengenai sejarah dan perkembangan puisi Rusia. Melalui studi literatur juga akan ditetapkan fokus studi berdasarkan masalah yang relevan dengan perkembangan puisi di Rusia. Studi dokumen dalam riset ini akan dilakukan dalam upaya memahami hubungan antara Barat dan Timur, khususnya di Rusia, dan pengaruhnya bagi perkembangan kesusastraan Rusia. 


\section{Analisis}

Puisi adalah bentuk karya sastra yang diminati masyarakat. Ungkapan perasaan dan kekaguman akan sesuatu atau seseorang dituangkan melalui kata-kata di dalam puisi. Puisi mengekspresikan pemikiran yang membangkitkan perasaan, merangsang imajinasi panca indera dalam susunan yang berirama. Semua itu penting untuk direkam dan diekspresikan, dinyatakan dengan menarik dan memberi kesan. Puisi merupakan rekaman dan interprestasi pengalaman manusia yang penting, diubah dalam wujud yang paling berkesan. $^{8}$

Dalam riset ini dilakukan analisis terhadap puisi yang mengangkat tema tentang Jawa dengan menggunakan pendekatan ekstrinsik. Teori representasi digunakan untuk menganalisis lima puisi berjudul Яванская Плянская (Penari Jawa), Боро-будур (Borobudur), Яванская Поэма (Puisi Jawa), Яванская Сад (Kebun Jawa), dan Яванский Гамелан (Gamelan Jawa). Puisi dianalisis tidak dengan melihat strukturnya melainkan dengan menghubungkan penggalan-penggalan teks yang memiliki makna. Menurut Stuart Hall, Representation connects meaning and languange to culture... Representation is an essential part of the process by which meaning is produced and exchanged beteween members of culture. ${ }^{9}$ Melalui representasi, suatu makna diproduksi dan dipertukarkan antaranggota masyarakat.

Kehadiran para penyair Rusia di Nusantara memberikan pengalaman dan juga imajinasi yang dituangkan ke dalam puisi. Keragamanan budaya di Nusantara telah memesona mereka.

\section{1. Яванская Плянская (Penari Jawa)}

Puisi Яванская Плянская (Penari Jawa) diciptakan oleh Konstantin Dmitrievich Balmont. la seorang penyair terkenal Rusia keturunan bangsawan pada periode simbolisme ${ }^{10}$ di Rusia. Sosoknya menjadi salah satu ikon di dalam periodesasi kesusastraan perak (silver age) di Rusia. Karyanya banyak mengangkat tema keindahan alam. Sebagai penyair, Balmont sering melakukan perjalanan mengunjungi negara-negara di Eropa, dan pengalaman perjalanannya menjadi inspirasi penulisan puisinya.

8. Pradopo, op.cit.h. 7 .

9. Stuart Hall (ed.), 'The Work of Representation'. Representation: Cultural Representation and Signifying Practices. (London: Sage Publication, 2003), 17.

10. Simbolisme pertama kali muncul di Perancis pada tahun 1886. Simbolisme dipelopori oleh Baudeleire dan dikembangkan oleh Verlaine, Rimbaud, dan Malarme. Simbolisme adalah aliran kesusastraan yang menampilkan perasaan pribadi penulis dan juga perasaan pembaca dengan semangat tak terbatas (D.S.Mirsky. 1968. History of Russian Literature. New York: Knopf.), 350. 


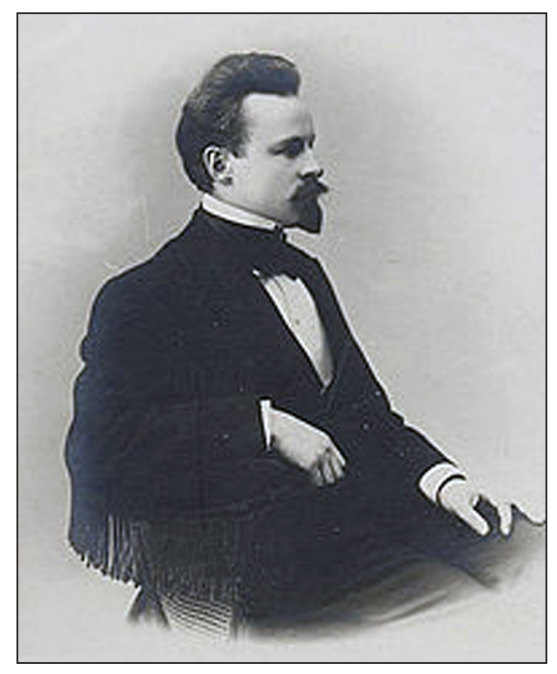

Foto 2. Konstantin Dmitrievich Balmont (sumber: lihat Bibliografi).

Selama perjalanan Balmont ke Asia, ia berkunjung ke Nusantara. la mengunjungi Jawa, Sulawesi, dan Sumatra. Kedatangan Balmont ke Pulau Jawa menghasilkan beberapa puisi. Kekagumannya pada keindahan alam dan budaya Jawa memberinya inspirasi.

Latar belakang kehidupan Balmont sebagai orang Eropa, memberinya pengalaman menarik selama kunjungannya ke Pulau Jawa. Inspirasi penulisan puisi diperoleh dari apa yang dilihat, didengar, dan dirasakannya. Selama kunjungannya ke Pulau Jawa, Balmont melihat pementasan tarian tradisional Jawa. la melihat bagaimana penari menggerakkan badannya sedemikian rupa mengikuti irama musik gamelan. Gerakan penari itu memberinya inspirasi dalam puisi berjudul Яванская Плянская (Penari Jawa).

Balmont sering melakukan perjalanan ke berbagai tempat, mengunjungi negara lain di Eropa. Selama perjalanan mengelilingi Eropa, kebudayaan yang dilihat Balmont tidak berbeda dengan kebudayaan Rusia. Oleh karena itu, kunjungan Balmont pada 1912 adalah yang pertama kali ke Jawa sehingga apa yang dialaminya menjadi hal baru. Kutipan di bawah ini menggambarkan bagaimana Balmont merasa dirinya tidak mengetahui apa pun. Balmont tidak mengetahui di mana dirinya berada sehingga merasa asing.

Где был я? Не знаю menepь

В чем был я ? Что знал я? Не знаю

Di mana aku dulu berada? Sekarang aku tak tahu Jadi apa aku dulu? Apa yang dulu aku tahu? Aku tak tahu sekarang

Penggalan puisi di atas merepresentasikan suasana di Jawa yang berbeda sama sekali dengan di Rusia. Suasana itu memberikan atmosfer baru bagi Balmont sehingga ia merasakan sesuatu yang asing di 
sekelilingnya. Pengalaman yang dirasakannya ketika menyaksikan tarian tradisional Jawa membuat dirinya merasa berada di dunia lain yang berbeda dan asing.

И в песни и в страсти мы ходим по краю

Лишь музьке верь

Мгновение знает

Мгновение играет

Dalam nyanyian dan gairah kami menepi

Hanya percaya pada musik

Dia tahu sekilas.

Dia bermain sebentar.

Pengalaman pertama Balmont menyaksikan tarian tradisional Jawa menjadi peristiwa menarik. Segala sesuatu yang dilihat dan didengarnya terasa asing bagi dirinya. Menurut Hall, things don't mean: we construct meaning, using representational system and concept signs. ${ }^{11}$ Oleh karena itu, konsep (dalam pikiran) dan tanda (bahasa) menjadi bagian penting yang digunakan dalam proses konstruksi atau produksi makna. Proses ini dimungkinkan karena hadirnya sistem representasi.

Selain gerak tari, musik yang mengiringi tarian Jawa juga terasa asing bagi Balmont dimana semua terasa berbeda dengan musik yang pernah didengarnya selama ini. Musik yang mengiringi tarian itu adalah musik tradisional yang merupakan salah satu bentuk kebudayaan yang berkembang di dalam kehidupan masyarakat. Musik tradisional menggambarkan kebudayaan yang dianut oleh masyarakat setempat dengan memiliki ciri khas, karakter, dan keunikan sendiri.

Musik yang dikenal oleh bangsa Rusia berakar dalam tradisi kesenian Rusia. Aliran musik yang digemari di Eropa adalah jenis musik klasik yang digunakan untuk perayaan di gereja, dan juga mengiringi acara yang diselenggarakan Tsar dan kaum bangsawan. Budaya dan kesenian yang dilihat selama ini oleh Balmont bernuansa Eropa, dan khususnya Rusia: gerak, tarian, dan nyanyian bersifat dinamis dengan irama yang musik yang dipengaruhi oleh adat, tradisi, dan budaya masyarakat setempat. 


\begin{abstract}
Вот рыбка совравалась
С дрохжащей лесы

Качались

Ikan kecil bertemu

Melepaskan dari kail

Saling berayun

Penggalan bait puisi di atas menggambarkan bagaimana para penari Jawa melakukan gerakan tarian seperti ikan yang berenang dan saling bertemu di sebuah kolam. Balmont melihat gerak tubuh para penari yang luwes seperti ikan yang berenang ke sana ke mari. Hal ini dilatari kepercayaan bangsa Rusia bahwa ajaran agama Kristen ortodoks menggambarkan ikan sebagai binatang yang melambangkan kesuburan dan kehidupan. Ikan saling bertemu dan akhirnya mereka bersatu untuk membentuk kehidupan baru.
\end{abstract}

\title{
2. Яванская Cad (Kebun Jawa)
}

Konstantin Dmitrievich Balmont dikenal sebagai penyair yang sering berkeliling dunia. Perjalanan Balmont ke Nusantara sekaligus melewati wilayah India, Afrika, Sri Lanka, dan Australia. Kedatangannya ke Nusantara pada 1912 menjadi pengalaman menarik baginya. Salah satu ketertarikannya pada keindahan alam, Balmont melihat aneka ragam hayati di Kebun Raya dan memberinya ide untuk menciptakan puisi Яванская Сад (Kebun Jawa).

Berdasarkan keterangan dari dokumen dan literatur, Kebun Raya yang dikunjungi Balmont terletak di Bogor. Kebun Raya itu adalah hutan buatan yang dibuat untuk menjaga kelestarian lingkungan, terutama menjadi tempat pemeliharaan berbagai benih kayu yang langka. Di samping itu, pada 1800, Gubenur Jenderal Belanda yang berkuasa pada masa itu, Thomas Stamford Raffles mempunyai gagasan membuat kebun yang indah di halaman istananya.

Akhirnya pada 18 Mei 1817, Gubernur Jenderal Belanda bernama Godert Alexander Gerard Philip van de Capellen secara resmi mendirikan Kebun Raya Bogor dengan nama 's Lands Plantentuin te Buitenzorg (buitenzorg berasal dari bahasa Belanda yang berarti "tidak perlu khawatir").

Kebun Raya tidak hanya berisi pohon langka dan indah tetapi juga aneka ragam spesies binatang, salah satu yang dilihat oleh Balmont adalah tokek atau gekko. Tokek adalah binatang yang hanya dapat ditemukan di daerah tropis. Persebaran tokek terjadi di Asia Selatan dan Asia Tenggara. Balmont menggambarkan bagaimana suara tokek yang didengarnya di Kebun Raya. 
И ящерица гекко, точно гном

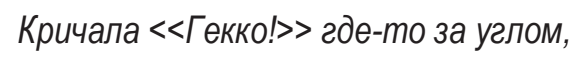

Tokek, yang begitu kecil

Menangis di sudut sana dengan suara 'tokek!

Tokek termasuk kelompok binatang yang hidup di lubang pepohonan atau rekahan batu dan gua. la aktif di senja hari dan malam hari, meski suara panggilannya kadang terdengar di siang hari.

Бся жизнь земная чудилась мене странной,

Я сам себе казался чьим-то сном,

Aku mengkhayal bahwa seluruh kehidupan duniaku terasa asing,

Aku seperti berada dalam mimpi orang lain,

Balmont mengagumi keindahan Kebun Raya. Selama berada di di sana, ia berkhayal berada di alam lain. Pemandangan alam sekitarnya dan juga pepohonan dan bebungaan mengelilingi dirinya, seolah-olah ia berada di negeri dongeng. Keindahan Pulau Jawa yang dikagumi Balmont diceritakan kepada rekannya A.N. Ivanova melalui surat pada bulan Oktober 1912.

It's evening. Java, Batavia. Hotel de France [...] I am holly immersed in my Javanese fairy tale, in these faces, in all my impressions of the East with its bright colours and mighty trees, its delicate pink lotuses and red acacia, its ineffably magnificent birds. For the whole past week I am being swept by a continual wave of impressions.

Kekaguman Balmont terhadap nusantara begitu luar biasa sehingga ia sangat terkesan. Kesan akan Jawa dan juga cerita mengenai Jawa memberinya gambaran mengenai Timur sebagai daerah yang subur dan indah.

\section{3. Яванская Поэма (Puisi Jawa)}

Valery Yakovlevich Bryusov adalah anak seorang pedagang di kota Moskow. la dikenal sebagai penyair, kritikus, dan juga sejarahwan yang suka bepergian keliling Eropa dan Asia. Dia dikenal sebagai salah satu pendiri simbolisme di Rusia. 


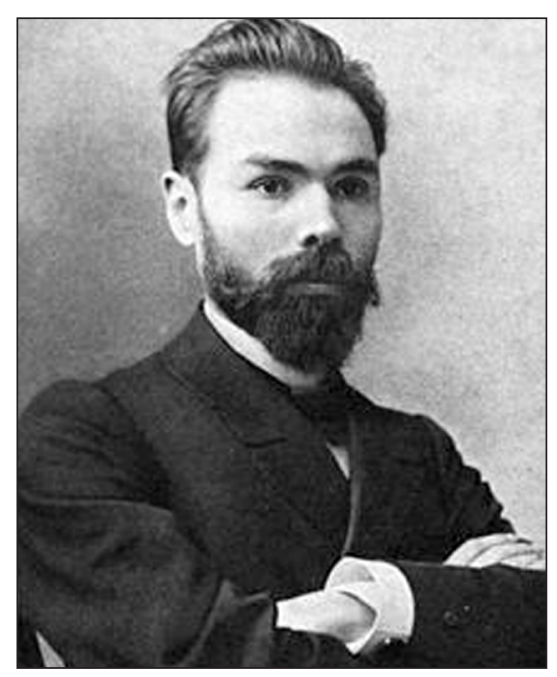

Foto 3. Valery Yakovlevich Bryusov (sumber: lihat Bibliografi).

Kunjungan Bryusov ke Pulau Jawa pada 1894 memberinya inspirasi untuk menciptakan puisi. Di dalam puisi Яванская Поэма (Puisi Jawa), ia menggambarkan kekagumannya pada keindahan alam dan juga budaya di Pulau Jawa.

\section{Ponтанье ветерка в садах сумарувунга}

В кустах замедленно и спит и видит сны

Desiran angin sumaruwung di taman

Di semak anak tertidur dan bermimpi

Penggalan bait puisi di atas menggambarkan bagaimana angin bertiup pada saat Bryusov berada di Pulau Jawa. Desiran angin menyejukkan suasana hatinya. Bryusov menggunakan kata сумарувунг уаng tidak memiliki padanan di dalam bahasa Rusia. Сумарувуне dalam bahasa Jawa menggambarkan suasana hati (yang kepanasan), tetapi terpaan angin mampu menghilangkannya.

Ты тробуешь о мать зубами рис

Ульбка черная моих ресниц-умри

Oh Ibu, kau mencoba beras ketan, di mulutmu

Senyum sedih bulu mataku-musnah

Bryusov juga menggambarkan salah satu kebiasaan Jawa yang dilakukan oleh rakyat, yaitu memakan jadah. Beras ketan atau disebut jadah melambangkan kemesraan hubungan antara laki-laki dan perempuan. Namun, kemesraan diakhiri dengan perpisahan yang menimbulkan kesedihan, layaknya kematian. 
Negara tropis yang memiliki cuaca hangat disukai oleh bangsa Eropa. Bryusov sangat menikmatinya, desiran angin di tengah cuaca daerah tropis yang bersuhu hangat. la menulis surat kepada rekannya.

Tropical days came again. I like sultry weather. My ancestors hail from the city of Kostroma, but lam sure that I have a celestial kinship with certain savages o the tropics. To be stark naked, to lie in wait -spear in hand-in the sun-bleached grass by a dried-up river, to bathe in the hot air, languidly listening to a distant growl of a lion-that is something after my heart, something I can readily understand (Bryusov 1973-1974: 575).

Kedatangan Bryusov ke Pulau Jawa menjadi sumber inspirasi baginya. Keindahan alam di Pulau Jawa membuat dirinya sangat mengagumi wilayah Timur.

\section{4. Боро-будур (Borobudur)}

Vladimir Yurievich Elsner adalah penyair dari Kiev yang terkenal. la mengagumi karya Anna Akhmatova, seorang penyair modern Rusia. Aleksandr Blok memberinya julukan "penerbit Kiev" karena ia menerbitkan beberapa karyanya yang terkenal.

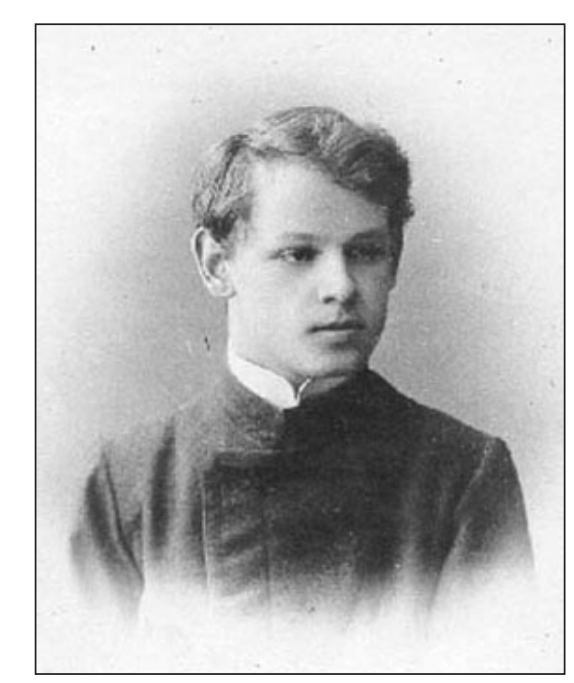

Foto 4. Vladimir Yurievich Elsner (sumber: lihat Bibliografi).

Elsner menulis puisi tentang Candi Borobudur yang keindahannya telah membuatnya terpesona. Candi Borobudur adalah candi agama Budha, dan relief yang dipahat di sana dilihat Elsner sebagai cerminan kehidupan Sang Budha.

Боробудур-священная обитель

В ней Будда полновластный повелитель 
Borobudur, kediaman yang suci

Tempat dimana Buddha adalah penguasa

И Множество его изображений

В граните воплотил народный гений

Banyak gambaran dirinya yang menjelma

Di batu granit, rakyat lihai membentuknya

Dari kutipan di atas, terlihat bahwa Elsner memandang Candi Borobudur sebagai representasi tempat suci bagi Budha. Candi Borobudur merupakan tempat pemujaan, dindingnya banyak dihiasi oleh relief yang menggambarkan keberadaan dan kegiatan Sang Budha.

Искусные строители сумели

В горе прорезать ходы подземелий

Mengatur para kuli ulung

Membuat ruang bawah tanah, di gunung

Рабы трудясь, как муравьи-термиты

Обтесывали глыбы-монолиты

Budak-budak bekerja keras seperti semut

Mengukir batuan besar

Полировали камни и сверлили

С камнями схожи от приставшей пыли

Memoles dan menggali batu yang tertutup oleh debu

Mereka menyerupai batu bersosok

Легли ступенями все выше, выше

Пологие ступенчатые крыши

mereka mendaki lebih tinggi, lebih tinggi

jejak langkah langit-langit 
Над ними силуэты устремили

Сквозные конусы, зубцы и шпили

Siluet membumbung tinggi di atasnya

Melalui puncak, benteng dan menara

Kutipan di atas menggambarkan bagaimana Elsner melihat Candi Borobudur sebagai sebuah bangunan yang berundak-undak, di puncaknya terdapat sebuah piramid. Di puncak tertinggi Candi Borobudur terdapat sebuah stupa yang merepresentasikan kesempurnaan hidup. Stupa utama juga melambangkan kebijaksanaan tertinggi, yaitu kasunyatan, kesunyian, dan ketiadaan sempurna artinya jiwa manusia sudah tidak terikat hasrat, keinginan, dan bentuk serta terbebas dari lingkaran samsara.

\author{
А поколенья мастеров отменных \\ Украсили и алтари и стены \\ generasi seniman yang tiada tanding \\ mereka menghias altar dan dinding \\ всем, что дает без всякого усилья \\ Твориу тропическое изобилье \\ Seluruhnya, yang diberikan cuma-cuma \\ Kekayaan tropis bagi seniman \\ Сплелись в чудовищный орнамент странный \\ Химеры, Грифы, змеи и лианы \\ Mengukir ke ornamen asing nan dahsyat \\ angan-angan, Grifin, ular dan Lian
}

Bait-bait puisi di atas melukiskan bagaimana Elsner mengagumi kekayaan relief yang ada di altar maupun dinding Candi Borobudur yang merupakan hasil karya para seniman yang sangat luar biasa. Mereka sangat kreatif sehingga mampu menghasilkan karya seni yang sangat tinggi. Kekaguman Elsner tidak terlepas dari karakteristik dari Candi Borobudur itu sendiri, reliefnya unik dan menarik. Relief cerita yang dipahatkan dalam Candi Borobudur sangat lengkap dan panjang, serta tidak pernah ditemukan di arena lain. 
Grifin dan ular adalah dua wujud binatang yang dilihat oleh Esner dalam relief Candi Borobudur. Apabila kedua binatang itu dimaknai seperti yang terdapat dalam mitos yang dipercayai oleh bangsa Eropa, masing-masing mempunyai makna, sebagai berikut.

1. Griffin, wujud binatang ini mempunyai makna jalan menuju keselamatan atau berarti juga pohon kehidupan. Binatang Griffin merupakan gabungan dari burung elang (yang merepresentasikan penguasa udara) dan singa (yang merupakan representasi api).

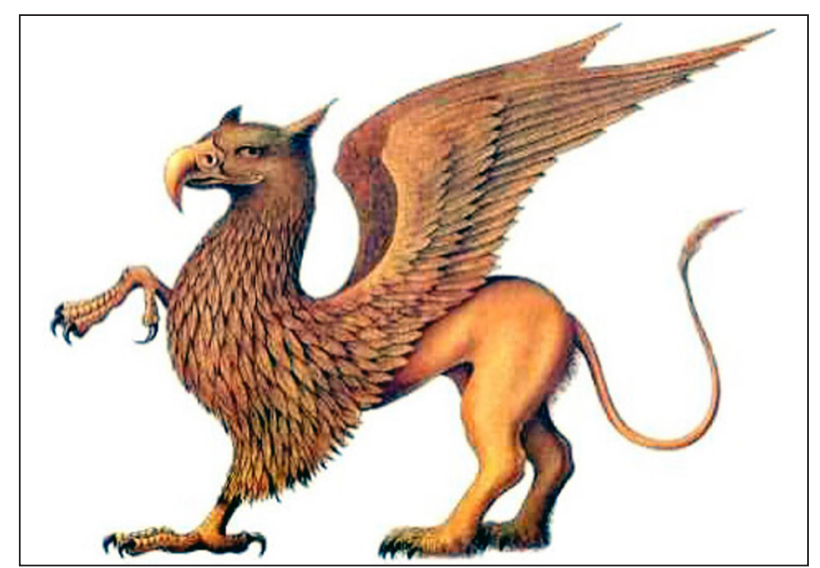

Ilustrasi 1. Griffin (Sumber: lihat Bibliografi).

2. Ouroboro, wujud binatang ular yang menelan ekornya sendiri menyatukan simbolisme lingkaran dan ular. Ini adalah elemen air padanan burung merak yang mewakili totalitas, kelahiran kembali, keabadian, dan putaran eksistensi. Semuanya menggambarkan tradisi Yunani kuno dan Mesir.

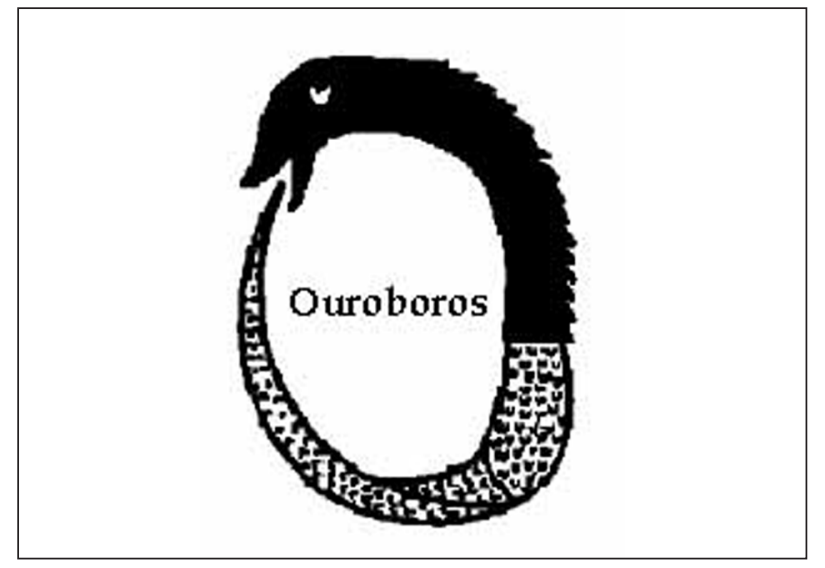

Ilustrasi 2. Ouroboro (Sumber: lihat Bibliografi).

Oleh karena itu, karya sastra Rusia yang menjadi bagian dari salah satu unsur kesenian mendapat pengaruh dari letak geografis Rusia yang terbentang di antara dua benua Eropa dan Asia. 


\section{5. Яванский Гамелан (Gamelan Jawa)}

Puisi ini diciptakan oleh Esper Esperovich Ukhtomsky. la adalah penyair yang memiliki hubungan dekat dengan lingkungan istana Tsar. Bahkan, penguasa istana menunjuk dirinya sebagai penasihat permasalahan teritorial Timur, sekaligus editor koran Saint Petersburg pada 1895.

Pada 1890-1891, Ukhtomsky melakukan perjalanan keliling dunia, salah satunya berkunjung ke Timur (Asia) mendampingi Pangeran Nikolay Alexandrovich Romanov (yang kelak akan menjadi Tsar Nikolay II) mengunjungi daerah di Pulau Jawa. Selama perjalanan, ia merasa kagum dan tertarik pada beberapa hal, di antaranya karakter penduduk Pulau Jawa, keindahan alam, bangunan tradisional, dan juga musik tradisional.

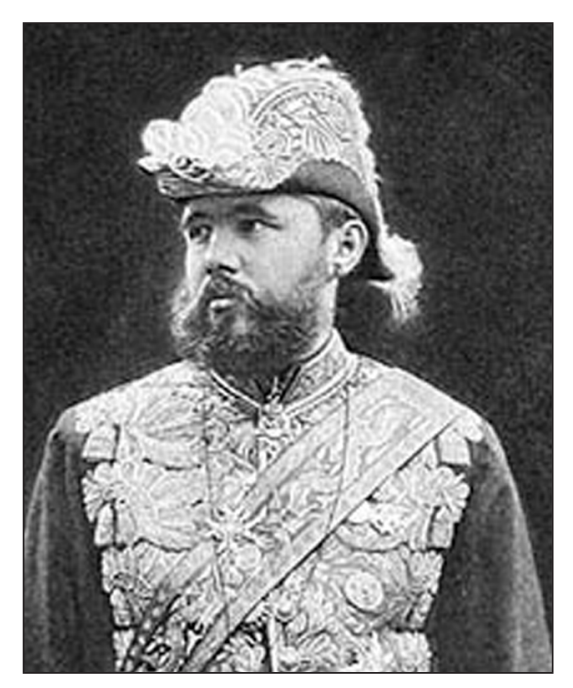

Foto 5. Esper Esperovich Ukhtomsky (sumber: lihat Bibliografi)

Selain menciptakan puisi, Ukhtomsky juga menulis memoar berisi catatan perjalanannya dengan Pangeran Nikolay Alexandrovich Romanov. la menulis dengan terperinci tujuan kepergiannya. Di dalam memoar itu, ia menuliskan kunjungan mereka ke Batavia, Kebun Raya Bogor, mendaki gunung Papandayan, berburu hewan, menyusuri wilayah Garut, mengunjungi Candi Borobudur, melihat pertunjukan wayang orang dan gamelan. ${ }^{12}$

Gamelan adalah salah satu alat musik tradisional yang sudah dikenal sejak zaman prasejarah di Pulau Jawa. Fungsi gamelan pada masa itu sebagai mediasi untuk memuja roh leluhur. Adapun kata gamelan berasal dari bahasa Jawa gamel yang berarti memukul, atau menabuh, diikuti akhiran (-an) yang menjadikannya kata benda. Gamelan sering dimainkan oleh orang Jawa yang tinggal di pedalaman. 108.

12. Vladimir I Braginsky dan Elena M. Diakonova. Images of Nusantara in Russian Literature. (Leiden : KITLV Press, 1999), 
Gamelan adalah musik tradisional yang berbeda dengan musik Barat. Di samping alat musik yang berbeda, laras nada yang dipakai gamelan bukan musik diatonik melainkan pentatonik. ${ }^{13}$

Puisi karya Ukhtomsky mengenai gamelan menggambarkan bagaimana alat musik itu dimainkan, dan alunan suaranya yang sangat unik bagi pendengaran Ukhtomsky. Gamelan menghasilkan bunyi-bunyian yang tidak pernah didengar Ukhtomsky sebelumnya. Berikut kutipan beberapa bait dalam puisinya.

Звуки манящие, звуки неясные,

Словно мечта или бред,-

Suara-suara menarik, suara-suara samar,

Bagai impian atau igauan -

Ukhtomsky menggambarkan bunyi gamelan seperti angin yang bertiup, bunyi-bunyian yang terdengar seperti sayup-sayup dengan irama yang pelan. Menurutnya, gamelan memiliki bunyi yang unik, seolah-olah pendengar diajak untuk memimpikan sebuah cerita dalam angan-angan.

Войны и казни, порой дуновение

Смертью клокочущих гор

Perang dan penghukuman, terkadang berbau

Gunung mengguncang dengan kematian

Все воплотилось в напев и видение

Все отуманило взор

Semua dituangkan dalam nada dan impian

Segalanya suram dalam pandangan

Что-то священное, что-то заветное

Создал душевный недуг

Sesuatu yang suci, sesuatu yang tersembunyi

Menciptakan jiwa yang sakit

13. Diatonik adalah tangga nada yang terdiri dari tujuh not yang berbeda dalam satu oktaf, nada, sedangkan Pentatonik adalah tangga nada yang terdiri dari lima nada (http://www.kompasiana.com/amadoleng/tangga-nada-diatonic-dan-pentatonic, diunduh tanggal 15 Juli 2016). 
Ukhtomsky mendengar alunan gamelan seperti memiliki bunyi yang khas, iramanya terkadang "bersifat sakral" sehingga orang yang mendengarnya menjadi khusuk dan hening.

\section{Kesimpulan}

Puisi menjadi bentuk karya sastra yang disukai bangsa Rusia. Kehadiran penyair memberi warna berbeda dalam kehidupan masyarakat. Яванская Плянская (Penari Jawa), Боро-будур (Borobudur), Яванская Поэма (Puisi Jawa), Яванская Сад (Kebun Jawa), dan Яванский Гамелан (Gamelan Jawa) adalah puisi yang ditulis berdasarkan kekaguman akan keindahan alam, budaya, tradisi, yang dilihat, didengar, dan dirasakan oleh Esper Esperovich Ukhtomsky, Konstantin Dmitriyevich Balmont, Valery Yakovlevich Bryusov, dan Vladimir Yurievich Elsner.

Balmont menggagumi keindahan gerakan para penari mengikuti irama musik gamelan sedemikian rupa. Gerakan mereka memberinya inspirasi dalam puisi berjudul Яванская Плянская (Penari Jawa). Begitu juga dengan keindahan pepohonan yang tumbuh di Kebun Raya, koleksi tanaman yang luar biasa memberinya inspirasi menulis puisi Яванская Саd (Kebun Jawa). Bryusov menulis puisi Яванская Поэма (Puisi Jawa) yang merepresentasikan keindahan alam di Jawa dan juga kehidupan masyarakatnya yang tetap memegang tradisi. Elsner menulis puisi Боро-будyp (Borobudur), tentang Candi Borobudur yang merupakan peninggalan masa Majapahit terbesar, keindahan relief dan bentuk candi mengundang decak kagumnya. Ukhtomsky menulis Яванский Гамелан (Gamelan Jawa) yang menceritakan pengalamannya mendengarkan alunan musik gamelan yang nadanya terdengar unik karena berbeda dengan musik klasik yang dimainkan di Rusia.

Puisi ditulis dengan menggunakan kata-kata yang tepat agar terdengarindah ketika kita membacanya. Pulau Jawa menimbulkan decak kagum pada para penyair Rusia yang dituangkan dalam untaian kata yang indah. Pesona Jawa tidak akan pernah hilang karena keindahan dan keunikan budayanya. Setiap penyair merasakan kekaguman tersendiri akan Pulau Jawa yang direpresentasikan ke dalam karya mereka.

\section{Daftar Pustaka}

All Music. "Alexander Pushkin". http://www.allmusic.com/artist/alexander-pushkin-mn0001543494/biography. АРХИВ РУССКОЙ КУЛЬТУРЫ. "Vladimir Yurievich Elsner". http://russian-authors.ru/ Ayobuka. "Rusia". http://ayobuka.com/2014/09/20/5-negara-terbesar-dan-terluas-di-dunia/russia/. 
Berdyaev, Nikolai. The Russian Idea. Diterjemahkan oleh Robert M. French. New York: The Macmillan Company, 1992.

Braginsky, Vladimir I dan Elena M. Diakonova. Images of Nusantara in Russian Literature. Leiden: KITLV Press, 1999.

Budianta, Melanie, Ida Sundari Husen, Manneke Budiman, Ibnu Wahyudi. Membaca Sastra: Pengantar Memahami Sastra untuk Perguruan Tinggi. Magelang: IndonesiaTera, 2003.

Budiono, Hersatoto. Simbolisme dalam Budaya Jawa. Yogyakarta: Hanindita Graha Widia, 2005.

Damono, Sapardi Djoko. Sosiologi Sastra: Sebuah Pengantar Ringkas. Jakarta: Pusat Pembinaan dan Pengembangan Bahasa, 1979.

Endraswara, Suwardi. Metodologi Penelitian Sastra. Yogyakarta: Centre of Academic Publishing Service, 2013.

Hall, Stuart, ed. Representation: Cultural Representation and Signifying Practices. London: Sage Publication, 2003.

Ihromi, T.O, ed. Pokok-pokok Antropologi Budaya. Jakarta: Yayasan Obor Indonesia, 1996.

Kaskus. Pulau Jawa. "5 Kabupaten Terluas di Jawa". http://www.kaskus.co.id/thread/559e4b7a1ee5df4967 8b4567/5-kabupaten-terluas-di-jawa/.

Koentjaraningrat. Kebudayaan Jawa. Jakarta: PN Balai Pustaka, 1984.

Kort, Michael. A Brief History of Russia. New York: Facts on File, Inc, 2008.

Kompasiana. "Tangga Nada Diatonic dan Pentatonic". http://www.kompasiana.com/amadoleng/tangga-nadadiatonic-dan-pentatonic.

Laurenson, Diana dan Alan Swingewood. The Sociology of Literature. London: Paladin, 1972.

Mirsky, D.S. History of Russian Literature. New York: Knopf, 1968

Ouroboros. http://www.crystalinks.com/ouroboros.html.

Pradopo, Rachmad Djoko. Pengkajian Puisi: Analisis Strata Norma dan Analisis Struktural dan Semiotik. Yogyakarta: Gadjah Mada University, 1990.

Sayuti, Suminto A. Puisi dan Pengajarannya: Sebuah Pengantar. Semarang: IKIP Press, 1985.

Soekanto, Soerjono. Sosiologi: Suatu Pengantar. Jakarta: P.T. RajaGrafindo Persada, 1990.

St. Margarets Community Website. Griffin. "The Brentford Griffin and Other Mysteries". http://stmgrts.org.uk/ archives/2009/05/the_brentford_griffin_and_other_mysteries.html. 
Suseno, Franz Magnis. Etika Jawa: Sebuah Analisis Falsafi tentang Kebijaksanaan Hidup Jawa. Jakarta: P.T. Gramedia, 1991.

Wikipedia. "Valery Yakovlevich Bryusov". https://en.wikipedia.org/wiki/Valery_Bryusov. ."Konstantin Dmitriyevich Balmont". https://en.wikipedia.org/wiki/Konstantin_Balmont. . "Esper Esperovich Ukhtomsky". https://en.wikipedia.org/wiki/Esper_Ukhtomsky. 